\title{
The influence of external factors on the credit risk in leasing industry
}

\author{
Gholamreza Farsad Amanollahi*
}

Department of Management and Accounting, Central Tehran Branch, Islamic Azad University, Tehran, Iran

\section{H R O N I C L E}

Article history:

Received October 28, 2015

Received in revised format

November 28, 2015

Accepted January 17, 2016

Available online

January 18, 2016

Keywords:

Leasing

Credit risk

External factors

\section{A B S T R A C T}

\begin{abstract}
Credit risk consists of probability of non-return, which may be in the form of bankruptcy or a decrease in financial and credit situation of the lessee. The variables are extracted from the Central Bank. In this study the independent variables are measured with six factors that are called external factors. The external factors are size of leasing, ownership interest rate, foreign exchange, inflation, and Gross Domestic Product (GDP). The present study uses related observations from 31 leasing companies from 2008 to 2013 to find out the determinants of the credit risk. The combined evidences suggest that internal factors such as upfront prepayment, credit insurance contract, security deposits, time and period contract, collateral and guarantees, contract amount, as well as external factors such as interest rate, inflation, foreign exchange, Gross Domestic Product infrastructure, and credit risk are determinants in the policy-making process involving the industrial leasing. Furthermore, the empirical results indicate the size of leasing and ownership are not the significant determinants of credit risk. The results of this dissertation provide several implications for policy-makers in the leasing industry. Policymakers will be better off employing different procedures for leasing activities in the leasing industry.
\end{abstract}

\section{Introduction}

One of the most important subjects to be taken into consideration in the process of allocation of a credit to a lessee is the evaluation of the credit risk of the lessee. Credit risk is simply defined as the probability/possibility that a lessee will fail to fulfill his/her obligations to the lessor during the contract period. Credit risk begins at the effective date of a contract agreement between a lessee and a lessor for borrowing or leasing purposes (Deelen et al., 2003). Business cycles, state of inflation, political stability or instability are among several factors influencing trust or lack of trust in the future of a lease contract. What one should always bear in mind in making an investment is the concept that risk of investment should be compatible with the rate of return of investment. So, acknowledging the need for credit risk analysis in financial institutions is very vital (Wilcox, 1971; Jurgita, 2011). Leasing includes several specialized steps based on the renting style where the contract is signed between two or more people. 
The lessee can be an individual or legal representative, who utilizes the advantages of the commodity or the commodity itself. This can be either a property, tenant, or durable consumer (Hildreth, 1993). The style can include a combination of economic transactions. Buying or renting can produce a contract of ownership. In other words, the contract is signed between a leasing firm, i.e. owner or lessor, and the user of the rented facility (Stewart, 1994). An essential subject for the allocation of credit to the lessee is associated with the credit risk assessment. When firms involve decision making they may look at firms' bonds for the evaluation of credit risk of lessee and bond issuers (Deelen et al., 2003; Woo \& Siu, 2004). Business cycles, inflation, political situations and many other factors play in the trust or lack of trust in the future.

An important issue in detecting a financial institution's credit such as leasing institutions and banks is associated with customers' credit risk assessment. Assessing the possibility of non-recovery of the anticipated return rate in valuating capitalization is called risk (Aven \& Renn, 2009), in other words, the lack of trust in investment future earnings. Business cycles, inflation, political situations and many other factors influence on one's lack of trust. A highly significant investment principle in all fields is that risk of investment ought to be in balance with the return of investment. Therefore, detecting skills of credit analysis in financial institutions is especially important (Bhattacharya, 2010).

When a customer applies for credit facilities or a lease, the institution ensues to give services after viewing customer's documents. Leasing tries to issue facilities to customers who are completely capable of repaying the principal/interest in a specified time (Krause, 2006). Modeling portfolio credit risk is a relevant issue in credit risk analysis. One may use a modeling portfolio credit risk to help for the development of an appropriate model. According to Moodys' Binomial Expansion Technique (BET), a model has been extensively implemented in finance and insurance industries. The BET model is adapted to believe that any defaults in a bond portfolio are binomially distributed. This is with the intention of handling the dependence of defaults that the notion of diversify score was introduced in the BET model (Lee, 2006).

\subsection{Credit Risk in Leasing Industry}

Credit risk can also be classified as credit risk. According to Schmit (2004) studied credit risk in leasing industry based on Leaseurope committee inputs. The study tried to show that none parametric simulation, named the Boot Strap technique could be used for credit risk assessment. This technique has also been used by Carey (1998) on the portfolio of private debt groups in the United States. This research can be effective in selecting a suitable standard for appointing capital sufficiency. The results of this research indicated that there was a direct relationship between credit risk and the term of rental contracts. Kisgen (2006) provided some evidences that ratings affect capital structure decisions if firms are near a credit risk upgrade or downgrade. Faulkender and Petersen (2006) reported that credit risk was related to better access to public debt markets and higher leverage.

\section{The research hypotheses}

Based on the proposed conceptual framework, several hypotheses will be developed in order to investigate the relationships between internal and default risk.

Credit Risk is an exposure to loss for the lack of payment by the borrower of an obligation on a loan agreement. Any credit obligation is considered default if more than 90 days pass the due date (Basel Committee on Banking Supervision, 2001). Few studies surround the idea of default risk and probability default (PD) along with the loss given default (Altman et al., 2005; Schmit, 2004; Schallheim, J. S., \& McConnell, 1985; Abdu and Hosseni, 2010). Financial instruments are often used to perform time-series analysis, cross-sectional analysis, panel-data analysis, profit analysis, trend 
analysis, correlation analysis, and regression analysis. The credit data are obtained from the Central Bank and Kanoon Leasing Association in Iran.

In this study, the independent variables are measured with 6 factors that are called external factors. The implications of the above mentioned external factors on financial institution and relationship between leasing credit risk and external variables are: size of leasing, ownership, interest rate, foreign exchange, inflation, and Gross Domestic Product (GDP).

\subsection{Size of Leasing (SILE)}

According to the theoretical literature discussed, size of leasing institution can influence default risk. Based on this view, the association between size of leasing firm and default risk can be either negative or positive, but negative results are dominant and prevalent. The size of a leasing institution is derived by dividing the number of contracts into total contracts.

Larger firms are often in less risk of bankruptcy or insolvency compared to smaller ones. In other words, size of a firm is inversely associated with business failure. It is claimed that larger firms are managed more effectively and with more effective organizational and financial infrastructures (e.g. Accounting Information Systems). Beattie et al. (1998) showed that size of a bank is associated with profitability of the banking system in Malaysia. They showed that size adversely affects commercial banks and also profitability of financial companies. In a research study, Glennon and Nigro (2005) showed that pooled default rate varies with firm size and cumulative default rate increases as firm size increases. Furthermore, differences in default rates are statistically important in accordance with size categories. Similar studies were conducted by Psillaki et al. (2010) on the role of size of leasing institution in profitability and also size of a financial institution in profitability in Iran.

In this research study the historical cumulative default rates are estimated by using the approach taken by Moody. In line with the research previously conducted, the role of this variable in default can be considered. Based on the above mentioned relationship between the size of lease and default, the related hypothesis is as follows:

Hypothesis 1: Size of a leasing company is negatively related to credit of a leasing company.

\subsection{Ownership $(O W N)$}

In accordance with the theoretical literature, ownership can influence credit risk. The relationship between ownership and default risk can be either negative or positive. This relationship for public ownership is dominantly negative and for private ownership it is dominantly positive. Ownership of a company is identified by the documents relating to deed of each company. The interpretations can be based on terms of loans, number of branches, deposits, and assets.

Sinha (2006) compared the Indian commercial banks (both public and private) with respect to each group's ability to generate income form the off balance activities through utilization of the Data Enveloping Approach. The results indicated that, in terms of the off balance sheet activities, the commercial banks of the public sector lag behind the commercial banks of the private sector.

Lind and Lundström (2010) showed that the public sector would proportionately sell and lease back fewer facilities in the next five years, or in which public-private ownerships are implemented. Since the number of sales has been relatively small in Sweden, it is not significant to discuss further longterm dynamic macro-effects, for instance if new large private asset owners develop more creative ways of monitoring "public sector" owning leasing assets. In the current study, the impact of ownership 
(private and public) on the relationship between internal and external factors and default is investigated through the following hypotheses:

Hypothesis 2: Public ownership is negatively related to credit of a leasing company.

Hypothesis 3: Private ownership is positively related to credit of a leasing company.

\subsection{Interest rate (INRA)}

According to theoretical literature, interest rate can have effect on credit risk. The association between interest rate and default risk can be either negative or positive, but positive results are more prevalent. Interest is defined as the amount of money a borrower of an asset (or a facility) pays to owner of the asset (or a facility) as a compensation for use of the asset (or a facility). In day to day context, it is the price normally paid for money borrowed from a financial firm, or money earned by depositing funds in a financial firm over a defined time period (Sullivan \& Sheffrin, 2003).

The interest rate is the rate applied by banks to their customers facilities. Higher interest rates may increase the risk of banks through an increase in default because high interest can increase the responsibility of borrowers into becoming a burden. Inflation may cause an increase in interest in the short term since the bank's costs of funds are increased. Therefore, interest rate and inflation are introduced separately. Bank returns are seen to be negatively related to interest rates. In light of the above rationale on the effect of interest rate on credit, the following hypothesis is made:

Hypothesis 4: Interest rate is positively related to credit of a leasing company.

\subsection{Foreign exchange (FOREX)}

In accordance with the theoretical literature, foreign exchange (rate) can influence default risk. The association between foreign exchange (rate) and default risk can be either negative or positive, but positive results are more dominant and prevalent. The foreign exchange rate is comparison of the parity of a country's currency to other countries' currencies. The spot exchange rate refers to the current exchange rate of currencies (Sullivan \& Sheffrin, 2003). In this study, FOREX refers to the exchange rate of the Iranian currency (Rial) against the United States Dollar (USD). Exchange rate changes can affect the amount of competitiveness of firms that are not covered against exchange rate risk. This has caused banks to have more exposure to exchange risk. Atindéhou and Gueyie (2001) discovered that on average, there was a positive significant relationship between a bank's stock returns and domestic currency appreciation and vice-versa. We predict default to be correlated with FOREX negatively. Therefore, the relationship between FOREX and credit risk is hypothesized as:

Hypothesis 5: Foreign exchange (rate) is positively related to credit of a leasing company.

\subsection{Inflation}

Based on theoretical literature, inflation can influence credit risk. The association between inflation and default risk can be either negative or positive, but the positive results are more dominant and prevalent. Generally, Inflation refers to a rise in prices of goods and services over a defined time period. When (rate) of inflation is high in a country, it means that prices rise, and buying power of people decrease over time. Inflation, also, reflect decrease in real value of a country's currency. Inflation is probable to be associated with high nominal interest rates, which will lead to reduce utilization and investment, which, in turn will cause reduction in profitability. In this study, positive relationship between inflation and default is hypothesized as:

Hypothesis 6: Inflation is positively related to credit of a leasing company. 


\subsection{Gross Domestic Product (GDP)}

Based on theoretical literature, gross domestic product can influence credit risk. The relationship between gross domestic product and default risk can be either negative or positive, but negative results are more dominant and prevalent. Gross national product is defined as the market value of the goods and services produced over a period of one year. GDP per capital also indicates a country's standard of living; it is not a measure of personal income (Akhigbe et al., 2007). When the economy is in a depression, it will decrease the demand for various mediation activities and investment. Therefore, the demand for lease and loan will be decreased. Default on existing loans will be increased. Thus, negative relationship between GDP and default is predicted, the following hypothesis is made:

Hypothesis 7: Gross domestic product (GDP) is negatively related to credit of a leasing company Estimation Model

\section{The proposed model}

Based on the above discussion, Eq. (1) illustrates the estimation model that is used in the present study:

$$
Y i t=\beta_{0}+\beta_{1} X_{i t}+\beta_{2} X_{j t}+\ldots+X_{m t}+e_{i t}
$$

where:

$Y_{i t}$ is the credit risk for company $i$ at period $t ; X_{j t}$ is the external factors and finally $e_{i t}$ is an error term.

Credit risk $=f($ SILE, OWN, INRA, FOEX, INF, GDP)

$C R_{\text {orit }}=\beta_{0}+\beta_{I} S I L E_{\text {or it }}+\beta_{2} O W N_{\text {or it }}+\beta_{3} I N R A_{\text {or it }}+\beta_{4} F O E X_{\text {or it }}+\beta_{5} I N F_{\text {or it }}+\beta_{6} G D P_{\text {or it }}+e_{\text {or it }}$

\subsection{Data Sources and Data Model}

The researcher uses official records and public documents. These are accessed by the extensive use of archives of the central Bank and the Stock Exchange. Six years of collected data are from 2008 to 2013. From the total of all leasing activities, approximately $90 \%$ belongs to 15 leasing companies and $10 \%$ to other companies with leasing activities (Central Bank, 2014). In reference to using the panel data model with its data limitation across companies over time ( 31 companies and 7 years), currently, it was not feasible to do cross-section or time-series study applications, therefore, the panel data analysis was applied.

\subsection{Estimation of Default Risk}

The focus was mainly on the determinants of leasing companies using external variables. This would include the various regression analysis carried out on 15 leasing companies in Iran from 2008 to 2013. In additional, it was imperative to assume that an underlying analysis was examined before the estimation model was tested. The assumptions to be addressed for the variables were the linearity and normality test of equal variance (Homoscedasticity). In additional, the correlation analysis was measured.

\subsection{Introductory Statistics}

Descriptive statistics and correlation matrix of all of the variables for the overall activities show the highest variability is related to the OWN (standard deviation $=0.241$ ). In contrast, the lowest variability 
corresponds to INRA (standard deviation $=0.017$ ). In a research containing several variables, besides knowing means and standard deviations of the dependent and independent variables, there is a need to know how one variable is related to another. In other words, it is sought to find out and realize nature, direction, and significance of bi-variant relationships of variables used in the study. Pearson Correlation matrix provides this information. The correlation coefficient ranges between -1 and +1 . There would be a perfect positive (negative) correlation between two variables if the correlation coefficient is +1 (1). For the overall activities, interest rate (INRA), foreign exchange (FOREX) and inflation (INF) are positively correlated to credit risk (CR). In contrast, size of leasing (SILE), ownership (OWN) and Gross Domestic Product (GDP) are negatively correlated to credit risk (CR). Moreover, the correlation results show that OWN is not closely related to credit risk (CR) and other variables. Similarly, Inflation (INF) is weakly correlated to other variables. Foreign exchange (FOREX) and interest rate (INRA) and Gross Domestic Product (GDP) are negatively correlated to most of the variables.

Results of the regression analysis can be seen in Table 1, the size of leasing and the ownership have insignificant association in the overall activities and in all other four kinds of activities. The interest rate for overall activities and the others have significant and positive relationship with credit risk (CR). Additionally, in the overall activities and all other four kinds of activities, inflation and foreign exchange have positive and significant relationship with credit risk (CR). Finally, the Gross Domestic Product in the overall activates and the private car has negative and significant association with credit risk (CR).

Table 1

Regression results of OLS estimation

\begin{tabular}{|c|c|c|c|c|c|c|}
\hline \multirow{2}{*}{$\begin{array}{l}\text { Independen } \\
\text { Variables }\end{array}$} & & \multirow[b]{2}{*}{$\begin{array}{c}\text { Overall } \\
\text { activities }\end{array}$} & \multirow[b]{2}{*}{ Private car } & \multirow[b]{2}{*}{ Public car } & \multicolumn{2}{|c|}{ Dependent Variable: CR } \\
\hline & & & & & Equipment & Housing \\
\hline \multirow{3}{*}{ SILE } & Coefficient & 0.0192 & 0.0301 & -0.0091 & -0.0022 & 0.0026 \\
\hline & Sig. & $0.8180 * *$ & $0.1028 * *$ & $0.7409 * *$ & $0.7342 * *$ & $0.7652 * *$ \\
\hline & Coefficient & 0.0007 & 0.0073 & 0.0012 & -0.0006 & -0.0006 \\
\hline \multirow[t]{2}{*}{ OWN } & Sig. & $0.9687 * *$ & $0.0917 * *$ & $0.5811 * *$ & $0.2244 * *$ & $0.1502 * *$ \\
\hline & Coefficient & -0.0003 & -0.0606 & -0.0154 & -0.0390 & -0.0587 \\
\hline \multirow[t]{2}{*}{ INRA } & Sig. & $0.0000^{*}$ & $0.0020^{*}$ & $0.0000^{*}$ & $0.0000^{*}$ & $0.0052 *$ \\
\hline & Coefficient & 0.3574 & 0.0506 & 0.1901 & 0.2345 & 0.1263 \\
\hline \multirow[t]{2}{*}{ FOREX } & Sig. & $0.0000 *$ & $0.0000^{*}$ & $0.0000^{*}$ & $0.0005^{*}$ & $0.0000 *$ \\
\hline & Coefficient & 0.0615 & 0.0899 & 0.0304 & 0.0308 & 0.1212 \\
\hline \multirow[t]{2}{*}{ INF } & Sig. & $0.0000 *$ & $0.0000^{*}$ & $0.0198 *$ & $0.0002 *$ & $0.0000 *$ \\
\hline & Coefficient & 0.0728 & 0.1317 & 0.0341 & 0.06318 & 0.1139 \\
\hline \multirow[t]{2}{*}{ GDP } & Sig. & $0.0489 *$ & $0.0000^{*}$ & $0.0461 *$ & $0.0368^{*}$ & $0.0498^{*}$ \\
\hline & Coefficient & -0.1050 & -0.3682 & 0.3389 & 0.1562 & 0.1144 \\
\hline \multicolumn{2}{|c|}{ R-squared } & 0.7585 & 0.7935 & 0.8738 & 0.8364 & 0.7610 \\
\hline \multicolumn{2}{|c|}{ Adjusted R-squared } & 0.7460 & 0.7455 & 0.8445 & 0.7984 & 0.7054 \\
\hline \multicolumn{2}{|c|}{ Durbin-Watson stat } & 1.6866 & 2.0002 & 1.7703 & 2.0199 & 1.8875 \\
\hline
\end{tabular}

Notes: * represent statistical significance at the, $5 \%$,

** represents statistical insignificance at the, $5 \%$,

\subsection{Forecasting Powers of the Model}

The compliance for the Logit model given with the McFadden $\mathrm{R}^{2}$ and the LR statistic for the correlated sample are calculated and demonstrated in Table 2. This shows that the LR is equal to 55.08 whereas the McFadden $\mathrm{R}^{2}$ for the Logit model is at $67 \%$, and statistically resulting at $1 \%$ which is within the corresponding asymptotic Chi-squared distribution. The explanatory power of the model was of two types for prediction error. A form I error occurs when the leasing companies are predicted to default but the result is non-default. A form II error occurs when the leasing companies are predicted not to 
default but the result is the default. As seen, the predictive attainment for default and non-default leasing companies and the two classes of errors, form I and form II is entailed. The cost of error form II is, though, more than the cost of error form I.

\section{Table 2}

The cost of form I errors and form II errors

\begin{tabular}{lcc} 
& Type I error & Type II error \\
& risk & Non-risk \\
\hline Original sample & 27 & 31 \\
Number of right predictions & 24 & 28 \\
Number of wrong predictions & 3 & 3 \\
Percentage of right predictions & 0.886 & 0.95 \\
\hline Overall accuracy of Logit & & 0.92963 \\
\hline
\end{tabular}

The correct prediction for risk leasing companies is about $89 \%$ when compared with $95 \%$ for a correct prediction of non-risk leasing companies. In general, model precision is about $93 \%$, an acceptable value for the purpose of predicting risk compared to other empirical models. The identifying indication for panel data models have a good overall fit - the probability ratio test statistics are significant at the $1.2 \%$ level of the random results binary Logit model. The probability ratio (LR) test declared at the foot of each Table highlights the results which indicate the random accomplish model is noteworthy as a minimum at the $1 \%$ level of significance.

\section{Conclusion}

The purpose of this study has been to investigate the determinants of risk in leasing companies with special focus on two types of variables of the internal and external factors. Applying different panel data regressions (OLS), the present study uses related observations from 31 leasing companies from 2008 to 2013 to find out the determinants of the credit risk. The combined evidences suggest that external factors such as interest rate, inflation, foreign exchange, Gross Domestic Product infrastructure, and credit risk are determinants in the policy-making process involving the industrial leasing. Furthermore, the empirical results indicate the size of leasing and ownership are not the significant determinants of credit risk. The results of this dissertation provide several implications for policy-makers in the leasing industry. Policy-makers will be better off employing different procedures for leasing activities in the leasing industry.

\section{Acknowledgement}

The authors would like to thank the anonymous referees for constructive comments on earlier version of this paper.

\section{References}

Abdoh Tabrizi, H. (2009). Financial management Tehran: Shahid Beheshti.

Altman, E. I., Brady, B., Resti, A., \& Sironi, A. (2005). The link between default and recovery rates: Theory, empirical evidence, and implications. Journal of Business-Chicago, 78(6), 2203-2227.

Altman, E. I. (1989). Measuring corporate bond mortality and performance. Journal of finance, 44(4), 909-922.

Akhigbe, A., Martin, A. D., \& Whyte, A. M. (2007). Partial acquisitions, the acquisition probability hypothesis, and the abnormal returns to partial targets.Journal of Banking \& Finance, 31(10), 30803101.

Aven, T., \& Renn, O. (2009). On risk defined as an event where the outcome is uncertain. Journal of risk research, 12(1), 1-11. 
Atindéhou, R. B., \& Gueyie, J. P. (2001). Canadian chartered banks' stock returns and exchange rate risk. Management decision, 39(4), 285-295.

Beattie, V., Edwards, K., \& Goodacre, A. (1998). The impact of constructive operating lease capitalisation on key accounting ratios. Accounting and Business Research, 28(4), 233-254.

Bhattacharya, K. M. (2010). Risk Management in Indian Bank. Mumbai: IND: Global Media.

Carey, M. (1998). Credit risk in private debt portfolios. Journal of Finance, 53(4), 1363-1387.

Deelen, L., Dupleich, M., Othieno, L., \& Wakelin, O. (2003). Leasing for Small and Micro Enterprises: A guide for designing and managing leasing schemes in developing countries. International Labour Organization.

Glennon, D., \& Nigro, P. (2005). Measuring the default risk of small business loans: A survival analysis approach. Journal of Money, Credit and Banking, 37(5), 923-947.

Faulkender, M., \& Petersen, M. A. (2006). Does the source of capital affect capital structure?. Review of financial studies, 19(1), 45-79.

Hildreth, W. B. (1993). State and local governments as borrowers: Strategic choices and the capital market. Public Administration Review, 53(1), 41-49.

Jurgita, B. (2011). An overview of the European leasing market in 2009. World Leasing Yearbook (edited by Adrian Hornbrook); A Euromoney Publication 2011, 46-55.

Kisgen, D. J. (2006). Credit ratings and capital structure. The Journal of Finance, 61(3), 1035-1072.

Krause, A. (2006). Risk Management. Bradford: GBR: Emerald Group Publishing Limited.

Lee, C. (2006). Advances in Quantitative Analysis of Finance and Accounting. River Edge, NJ, USA: World Scientific.

Lee, C. F. (2009). Advances in quantitative analysis of finance and accounting (Vol. 7). Airiti Press.

Lind, H., \& Lundström, S. (2010). Owning vs leasing of real properties in the Swedish public sector. Journal of Corporate Real Estate, 12(3), 175-184.

McConnell, J. J., \& Schallheim, J. S. (1983). Valuation of asset leasing contracts. Journal of Financial Economics, 12(2), 237-261.

Psillaki, M., Tsolas, I. E., \& Margaritis, D. (2010). Evaluation of credit risk based on firm performance. European Journal of Operational Research,201(3), 873-881.

Rahmani, A. (2011). Leasing in Iran. World leasing yearbook 2011, 1 (Eurmoney yearbook), 547.

Schallheim, J. S., \& McConnell, J. O. H. N. (1985). A model for the determination of "fair" premiums on lease cancellation insurance policies. The Journal of Finance, 40(5), 1439-1457.

Schmit, M., \& Stuyck, J. (2002, September). Recovery rates in the leasing industry. In Working Paper presented at Leaseurope's Annual Working Meeting, Salzburg. 1024-1025.

Schmit, M. (2004). Credit risk in the leasing industry. Journal of banking \& finance, 28(4), 811-833.

Sinha, R. P. (2006). Capital adequacy of Indian commercial banks: Some empirical results. The IUP Journal of Financial Economics, 4(1), 25-44.

Siu, T. K., Ching, W. K., Fung, E. S., \& Ng, M. K. (2005). Extracting information from spot interest rates and credit ratings using double higher-order hidden Markov models. Computational Economics, 26(3-4), 69-102.

Stewart, W. J. (1994). Introduction to the numerical solutions of Markov chains. Princeton Univ. Press.

Sullivan, A., \& Sheffrin, S. M. (2003). Economics: Principles in action. Upper Saddle River, New Jersey 07458: Pearson Prentice Hall.

Tang, L. (2008). Credit risk. Master of Philosophy, Hong Kong, Hong Kong.

Wilcox, C. (1971). Public policies toward business. RD Irwin.

Woo, W. H., \& Siu, T. K. (2004). A dynamic binomial expansion technique for credit risk measurement: a Bayesian filtering approach. Applied Mathematical Finance, 11(2), 165-186.

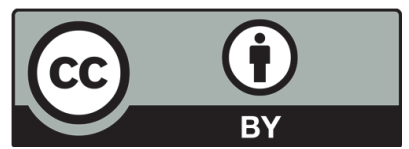

(C) 2016 by the authors; licensee Growing Science, Canada. This is an open access article distributed under the terms and conditions of the Creative Commons Attribution (CC-BY) license (http://creativecommons.org/licenses/by/4.0/). 